\title{
BIOMASS FLOW AND DEFOLIATION PATTERN IN ALEXANDERGRASS FERTILIZED WITH NITROGEN
}

\author{
FLUXOS DE BIOMASSA E PADRÕES DE DESFOLHAÇÃO EM PAPUÃ \\ FERTILIZADO COM NITROGENNIO
}

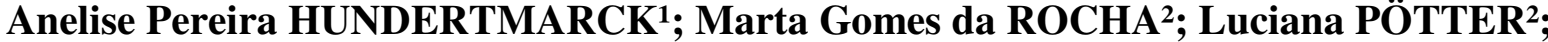 Paulo Roberto SALVADOR ${ }^{3}$; Tuani Lopes BERGOLI ${ }^{3}$; Érica Dambros de MOURA ${ }^{4}$; Pedro Arthur de Albuquerque NUNES ${ }^{5}$; Maria José de Oliveira SICHONANY ${ }^{3}$}

1. Zootecnista, Mestre, Egressa do Programa de Pós Graduação em Zootecnia, Universidade Federal de Santa Maria, Santa Maria, RS, Brasil; 2. Professora, Doutora, Programa de Pós Graduação em Zootecnia, Universidade Federal de Santa Maria, Santa Maria, RS, Brasil.mgdarocha@gmail.com; 3. Zootecnista, Mestre, Doutorando, Programa de Pós Graduação em Zootecnia, Universidade Federal de Santa Maria, Santa Maria, RS, Brasil; 4. Zootecnista, Mestre, Egressa do Programa de Pós Graduação em Zootecnia da Universidade Federal do Rio Grande do Sul, Porto Alegre, RS, Brasil; 5. Engenheiro Agrônomo, Mestre, Doutorando, Programa de Pós Graduação em Zootecnia da Universidade Federal do Rio Grande do Sul, Porto Alegre, RS, Brasil.

\begin{abstract}
The determination of biomass flows can assist on improving pasture fertilization techniques, contributing to identify the best management methods and, in relation the use of fertilizers. Nitrogen deficiency in pastures can reduce forage production. On the other hand, there is an environmental concern on nitrogen (N) losses when this nutrient is used in excess and this concern guides the search for new grazing systems that optimize its use. Leaf biomass flow, intensity and frequency of defoliation were evaluated in Alexandergrass (Urochloa plantaginea (Link) Hitch) fertilized with Zero, 100,200 or $300 \mathrm{~kg} /$ ha nitrogen $(\mathrm{N})$ as urea. The grazing method was put and take stocking in order to keep the forage mass at 3,000 kg/ha DM. The experimental animals were Angus heifers with an initial age of 15 months and body weight of $241.5 \pm 5 \mathrm{~kg}$. The experimental design was completely randomized following a repeated measure arrangement, with four treatments and variable number of experimental units. The highest growth of leaf blades was achieved with $100 \mathrm{~kg} / \mathrm{ha} \mathrm{N}$. Senescence and intake flows and defoliation intensity were similar among the N levels used. The frequency of return to the same tiller (days) was influenced by $\mathrm{N}$ levels and evaluation periods. Our findings recommend the use of $100 \mathrm{~kg} / \mathrm{ha} \mathrm{N}$ in Alexandergrass pasture.
\end{abstract}

KEYWORDS: Morphogenesis. Continuous grazing. Urea. Urochloa plantaginea (Link) Hitch.

\section{INTRODUCTION}

Pastures are the most practical and economical way to feed cattle and sustain the livestock production in Brazil. Nitrogen deficiency in pastures can reduce forage production, because this nutrient participates in different enzymatic reactions in plant tissues, increasing carbon sequestration (LEMAIRE; CHAPMAN, 1996). On the other hand, there is an environmental concern on nitrogen losses $(\mathrm{N})$ when this nutrient is used in excess and this concern guides the search for new grazing systems that optimize its use.

In Southern Brazil, the Alexandergrass (Urochloa plantaginea (Link) Hitch) has been studied as a forage species because it occurs spontaneously in areas cultivated with summer crops, having favorable characteristics for grazing (OLIVEIRA NETO et al., 2013). Studies involving the use of nitrogen in Alexandergrass pasture indicated a positive response of this forage to this nutrient (ADAMI et al., 2010; SARTOR et al., 2014).
The determination of biomass flows can assist on improving pasture fertilization techniques, contributing to identify the best management methods and, in relation the use of fertilizers, its action on growth and use of forage (BIRCHAM; HODGSON, 1983). In addition to the leaf biomass flows, knowledge of defoliation patterns (intensity and frequency) can provide information to minimize losses of leaf tissues by senescence. The intensity and frequency of removal of leaf blades are important factors determining the plant canopy structure and can determine the plant response to the action of herbivore.

There is still little research about biomass flows on tropical pasture grasses (LOPES et al., 2013). In Alexandergrass, the biomass flow and defoliation patterns can be altered by providing protein salt (ELOY et al., 2014). However, these flows are similar when beef heifers were supplemented with different frequencies (SALVADOR et al., 2014). There is no literature showing the effect of $\mathrm{N}$ levels on biomass flows of Alexandergrass. In this context, this study aimed to measure the growth, senescence and intake flows of 
leaf blades and the defoliation patterns of Alexandergrass fertilized with different levels of $\mathrm{N}$.

\section{MATERIAL AND METHODS}

This experiment was approved by the Ethics Committee for Animal Experimentation of Universidade Federal de Santa Maria (protocol 070/2013).This study was conducted at the Federal University of Santa Maria (UFSM), located in the Central Depression of Rio Grande do Sul State, Brazil, from December 2012 to May 2013. The climate in the region is humid subtropical, according to the Köppen classification. The soil is classified as Paleudalf (EMBRAPA, 2006). The mean values for the chemical characteristics of the soil in the experimental area were: $\mathrm{pH}-\mathrm{H}_{2} \mathrm{O}: 5.8$; clay: 18 g/100 g; P: $15.8 \mathrm{mg} / \mathrm{L} ; \mathrm{K}: 85.6 \mathrm{mg} / \mathrm{L}$; OM: 2.68 $\mathrm{g} / 100 \mathrm{~g} ; \mathrm{Al}^{3+}: 0.7 \mathrm{cmolc} / \mathrm{L} ; \mathrm{Ca}^{2+}: 5.3 \mathrm{cmolc} / \mathrm{L}$; $\mathrm{Mg}^{2+}: 2.5 \mathrm{cmolc} / \mathrm{L}$; CEC pH7: 11.4. Meteorological data for the study period were obtained from the UFSM Meteorological Station.

Alexandergrass (Urochloa plantaginea (Link) Hitch) pasture was established by an existing seed bank in the area in December 2012. Paddocks received fertilization with phosphorus and potassium based on the recommended fertilization and liming for the states of Rio Grande do Sul and Santa Catarina (ROLAS, 1994). The experimental area (5.6 ha) was divided into six experimental units of 0.4 ha and four experimental units of 0.8 ha, plus a contiguous area of 2.8 ha for the put-and-take animals.

We evaluated the biomass flow, defoliation intensity and frequency on Alexandergrass pasture fertilized with Zero, 100, 200 or $300 \mathrm{~kg}$ of nitrogen $(\mathrm{N}) /$ ha as urea. The total amount of $\mathrm{N}$ was split into three doses of similar amounts, the first applied at the time of soil tillage and the others on February $4^{\text {th }}$ and March $3^{\text {rd }}$. Morphogenetic evaluations for determining the biomass flow and the defoliation patterns were performed from February $15^{\text {th }}$ to March $25^{\text {th }}\left(1^{\text {st }}\right.$ period $)$ and March $26^{\text {th }}$ to May $2^{\text {nd }}$, 2013 ( $2^{\text {nd }}$ period $)$.

In each experimental unit, three Angus heifers (experimental animals) with an initial age of 15 months and body weight of $241.5 \pm 5.7 \mathrm{~kg}$ were used. The grazing method was put-and-take stocking to maintain $3000 \mathrm{~kg}$ dry matter (DM)/ha of forage mass. The forage mass was evaluated every 10 days by the direct visual estimation method with double sampling. At the same occasions, forage sward height was measured being considered as the distance $(\mathrm{cm})$ from the ground surface to the average height of folding leaves. The forage was cut at ground level and the collected samples were split into two sub-samples for determination of DM content. Structural components were separated manually into: leaf (blade) and stem (leaf sheath + stem) of Alexandergrass. After separation and drying of structural components, we determined the percentage participation of leaf blades and stems. Next, we calculated the leaf:stem ratio. Animals were weighed every 28 days, following a 12-hour fast from solids and liquids.

The stocking rate (SR; $\mathrm{kg} / \mathrm{ha}$ body weight) was calculated according: $\mathrm{SR}=((\mathrm{BWe} * \mathrm{TP})+$ $(\mathrm{BWa} * \mathrm{D})) / \mathrm{TP}$. Were $\mathrm{BWe}=$ sum of the body weight of experimental animals ( $\mathrm{kg} / \mathrm{ha}) ; \mathrm{BWa}=$ average weight of animals used for adjustment in the stocking rate; $\mathrm{TP}=$ trial period; $\mathrm{D}=$ number of days in the experimental unit. The adjustment of stocking rate was performed every 10 days, according to Heringer and Carvalho (2002).

Tiller population density (tillers $/ \mathrm{m}^{2}$ ) was assessed by counting Alexandergrass tillers found in three $\left(0.0625 \mathrm{~m}^{2}\right.$ each $)$ fixed squares in each experimental unit. The tillers were cut at ground level, counted and weighed after drying in a circulating air oven at $55^{\circ} \mathrm{C}$ for $72 \mathrm{~h}$.

Morphogenetic and structural characteristics were measured by the marked tiller technique (CARRÈRE; LOUAULT; SOUSSANA, 1997). In each experimental unit, 30 tillers were marked with colored plastic rings in the paddocks fertilized with Zero and $100 \mathrm{~kg} / \mathrm{ha}$ of $\mathrm{N}$ and 15 tillers in the paddocks fertilized with 200 and $300 \mathrm{~kg} / \mathrm{ha}$ of $\mathrm{N}$. This difference in tillers marked number was due to the difference in the paddocks area. At the marked tillers, the leaf and the stem length $(\mathrm{cm})$ were measured twice a week. The leaf appearance rate (LAR; leaf/degree-day), leaf expansion rate (LER; $\mathrm{cm} /$ degree-day) stem expansion rate (SER; $\mathrm{cm} /$ degree-day), leaf senescence rate (LSR; $\mathrm{cm} /$ degree-day), phyllochron (degree-day), number of fully expanded and expanding leaves were calculated (LEMAIRE; CHAPMAN 1996).

Leaf tissue flow, leaf blade intake, potential efficiency and actual utilization and net balance of leaf blades were calculated according to Pontes et al. (2004). For calculating the defoliation intensity (proportion of the length removed), we identified the grazed leaf blades (fully expanded, expanding and senescent leaves) in each period and used the formula: defoliation intensity $=($ (initial length - final length)/initial length)*100. The frequency of defoliation (days of return to the same tiller) was calculated by the formula: frequency of defoliation= $1 / \mathrm{NC} /(\mathrm{NCP} * \mathrm{EL})$, where: $\mathrm{NC}=$ number of contacts; 
$\mathrm{NPC}=$ number of possible contacts; $\mathrm{EL}=$ evaluation length.

To determine the total grazing area, the paddock was considered as $100 \%$. Paddock area divided by the frequency of defoliation corresponds to a daily area used by grazing animals. The number of defoliation during the lifespan of Alexandergrass leaves was calculated by dividing the lifespan of leaves by the thermal sum between defoliations.

A completely randomized design following a repeated measurement arrangement was used, with four treatments and three (200 and $300 \mathrm{~kg} \mathrm{~N} / \mathrm{ha}$ ) and two (Zero and $100 \mathrm{~kg} \mathrm{~N} / \mathrm{ha}$ ) area replications per treatment. Statistical analyses were performed using the 'Mixed' procedure of SAS software for variables that showed normality of residuals. We used a mixed model with fixed effects (levels of $\mathrm{N}$, periods of assessment and their interactions) and random effects (the residual and the nested paddocks for each amount of $\mathrm{N}$ ). We performed a structure selection test, following the Bayesian Information Criterion (BIC), to determine the model that best fit the data. The general mathematical model refering to the analysis of variance was represented by: Yijk $=\mu+\mathrm{Ti}+\mathrm{ek}: \mathrm{I}+\mathrm{Pj}+\left(\mathrm{T}^{*} \mathrm{Pij}\right)+\mathrm{kijk}$, where: $\mu=$ mean of all observations; $\mathrm{Ti}=$ is the fixed effects of treatments; ek:i= is the random effect of the paddock nested in the treatments (error a); $\mathrm{Pj}=$ is the fixed effect of the periods; $\mathrm{T} * \mathrm{Pij}=$ interaction treatments*periods; $\mathrm{kijk}=$ residual experimental error (error $b$ ). The interaction between treatments and evaluation periods was significant at 5\% probability and variable responses were modeled according to $\mathrm{N}$ levels in each evaluation period. In regression analysis, the model was selected based on the significant level of linear and quadratic coefficients, using the Student's t-test (Test "t"; 5\% probability). When not fitted to regression models, the mean values were compared using the 'Ismeans' procedure (10\% of probability). The variables actual and potential utilization efficiency (AUE and PUE, respectively) were transformed into logarithm $\left(\mathrm{LOG}_{10}\right)$ and net balance of leaf blades to sum of squares (SQRT(Y)).

\section{RESULTS}

The average temperature during the experimental period (December 2012 to May 2013) was $22.5^{\circ} \mathrm{C}$. Rainfall $(\mathrm{mm})$ events occurred in December (293.0), January (145.3), February (97.7), March (188.6), April (147.7) and May (71.7 mm).

No interaction between levels of nitrogen $(\mathrm{N})$ applied $\times$ evaluation periods for the forage mass (FM), canopy height and leaf:stem ratio were found
( $\mathrm{P}>0.05)$. Calves were kept in paddocks with similar forage mass $(\mathrm{FM} ; 2,969 \pm 82 \mathrm{~kg} / \mathrm{ha}$ dry matter $(\mathrm{DM}) ; \mathrm{P}=0.6398)$. The greatest value of $\mathrm{FM}$ was found in the second evaluation period $(3,050.1$ $\mathrm{kg} / \mathrm{ha} \mathrm{DM}$ ) while the value observed in the first period was $2,888 \mathrm{~kg} / \mathrm{ha}$ DM.

The average height of the canopy was 19.7 $\pm 0.9 \mathrm{~cm}$, similar for the different levels of $\mathrm{N}$ $(\mathrm{P}=0.6442)$. The canopy height in the first period $(23.6 \mathrm{~cm})$ was higher by $33.1 \%$ compared to the second period $(15.8 \mathrm{~cm})$. The stocking rate was unchanged $(1,883.3 \pm 156 \mathrm{~kg} / \mathrm{ha} \mathrm{BW})$ by the use of $\mathrm{N}$ levels and evaluation periods $(\mathrm{P}>0.10)$.

No interaction was detected between levels of $\mathrm{N} \times$ evaluation periods $(\mathrm{P}>0.05)$ for the stem length. The average stem height $(15.5 \mathrm{~cm})$ was not altered by $\mathrm{N}$ levels $(\mathrm{P}=0.6494)$. The length of the stem observed in the first evaluation period (21.1 $\mathrm{cm})$ was $9.1 \mathrm{~cm}$ higher than the value in the second period $(\mathrm{P}<0.001)$. In both periods, the stem length was highly and positively associated with canopy height $(r=0.96$; $P<0.0001)$.

The leaf:stem ratio (LSR; $0.45 \pm 0.03$ ) was similar $(\mathrm{P}=0.1935)$ among the $\mathrm{N}$ levels evaluated. In the second period, the ratio was reduced $(\mathrm{P}<0.001)$ by $60 \%$ compared to the value observed in the first period (0.65).

Also, no interaction was found between $\mathrm{N}$ levels $\times$ evaluation periods $(\mathrm{P}>0.05)$ and there was no effect of $\mathrm{N}$ levels on the variables leaf appearance rate, phyllochron (Table 1) and leaf lifespan (534.6 \pm 35 degree-day; $\mathrm{P}=0.4223$ ). The leaf appearance rate and the phyllochron differed between the evaluation periods (Table 1).

The variables leaf and stem expansion rates, leaf senescence rate and length of leaf blades showed no interaction between $\mathrm{N}$ levels $\times$ evaluation periods $(\mathrm{P}>0.05)$. The leaf expansion rate differed among the $\mathrm{N}$ levels and the evaluation periods (Table 1). With the application of $100 \mathrm{~kg} / \mathrm{ha}$ $\mathrm{N}$, leaf expansion rate was $35.3 \%$ higher in relation to the other levels tested, which were not different to each other $(0.055 \mathrm{~cm} /$ degree-day $)$. The leaf expansion rate was higher by $55.8 \%$ in the first period compared to the second (Table 1).

The stem expansion rate was similar between the evaluated $\mathrm{N}$ levels $(\mathrm{P}>0.10)$ but differed between periods (Table 1). In the first period, this rate was higher than that observed in the second period (Table 1).

The leaf senescence rate differed between the levels of $\mathrm{N}$ and the evaluation periods (Table 1). This variable was $36.4 \%$ higher when $\mathrm{N}$ was not used, compared with the levels of 200 and $300 \mathrm{~kg} / \mathrm{ha}$ $\mathrm{N}(0.042 \mathrm{~cm} /$ degree-day). The leaf senescence rate 
of Alexandergrass fertilized with $100 \mathrm{~kg} / \mathrm{ha} \mathrm{N}$ was not different from that observed levels Zero, 200 and $300 \mathrm{~kg} / \mathrm{ha} \mathrm{N}$ (Table 1). The senescence rate was higher in the first period in relation to the value verified in the second period (Table 1). This variable was positively associated with canopy height $(\mathrm{r}=0.79 ; \mathrm{P}=0.0005)$ and the stem length $(\mathrm{r}=0.69 ; \mathrm{P}=0.0007)$.

Table 1. Morphogenetic and structural characteristics, phyllochron, biomass flows and actual efficiency utilization of Alexandergrass fertilized with nitrogen $(\mathrm{N})$

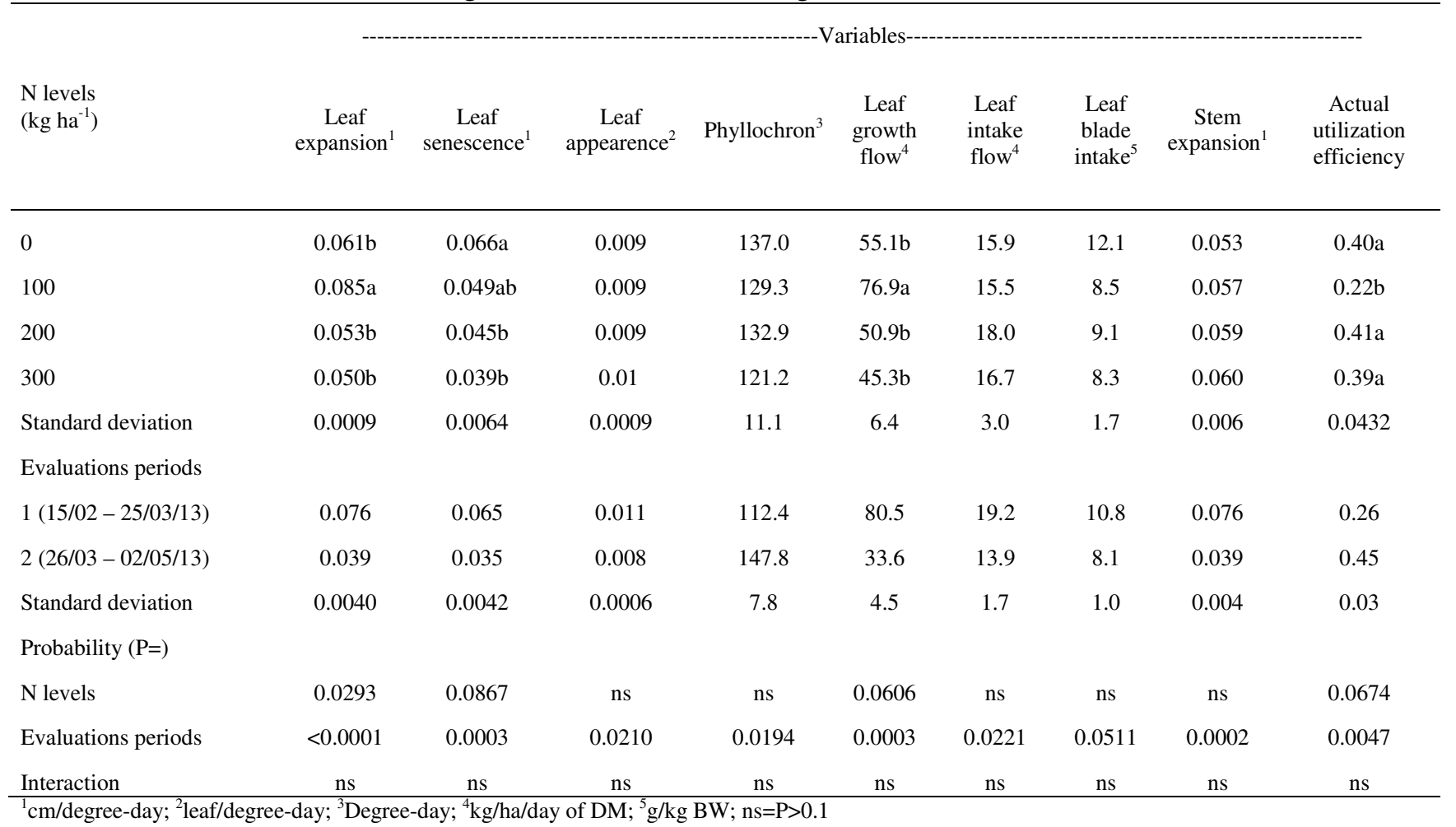

The length of leaf blades of Alexandergrass $(7.4 \pm 0.3 \mathrm{~cm} ; \mathrm{P}=0.5328)$ was similar between the different levels of $\mathrm{N}$ applied but differed according to the evaluation periods $(\mathrm{P}<0.0001)$. In the first period, the leaf blades were longer $(9.5 \mathrm{~cm})$ in relation to the second period $(6.1 \mathrm{~cm})$.

An interaction between levels of $\mathrm{N} \times$ evaluation periods for the number of green leaves per tiller was observed $(\mathrm{P}=0.0164)$. In the first period, regardless of $\mathrm{N}$ dose, the number of leaves per tiller was similar (4.9 leaves/tiller). In the second evaluation period, values of number of leaves per tiller fit to a negative linear regression model $\left(\hat{\mathrm{Y}}=3.81-0.0017 \mathrm{x} ; \mathrm{r}^{2}=0.5573, \mathrm{P}=0.0132\right)$.

For tiller density, no interaction was observed between levels of $\mathrm{N} \times$ evaluation periods $(\mathrm{P}>0.05)$. Tiller density was similar among different $\mathrm{N}$ levels applied $\left(1123.5 \pm 222\right.$ tillers $\left./ \mathrm{m}^{2}\right)$, and this value remained constant during the evaluation periods ( $\mathrm{P}>0.10)$.

No interaction $\mathrm{N}$ levels $\times$ evaluation periods $(\mathrm{P}>0.05)$ for the removal of leaf blades was observed. Regardless of $\mathrm{N}$ levels, the removal intensity was $60.3 \pm 4 \%$, and similar during the evaluation periods $(\mathrm{P}>0.05)$.

For the frequency of return to the leaf blade (FR), in days, an interaction was registered between levels of $\mathrm{N} \times$ evaluation periods $(\mathrm{P}=0.0107)$. In the first period, the frequency of return was lower (6.4 days) when used the levels Zero, 100 and $300 \mathrm{~kg} / \mathrm{ha}$ $\mathrm{N}$. When applied $200 \mathrm{~kg} / \mathrm{ha} \mathrm{N}$, heifers returned with 5.6 day interval. In the second evaluation period, the frequency of return showed a quadratic behavior $\left(\hat{Y}=5.31+0.0042 \mathrm{x}-0.00002 \mathrm{x}^{2} ; \mathrm{r}^{2}=0.7214 ; \mathrm{P}=0.0114\right)$ with a lower frequency when applied $105 \mathrm{~kg} / \mathrm{ha} \mathrm{N}$. Significant correlations among the frequency of return to the same tiller with the structural characteristics of the canopy or with the stocking rate were not found in any period of evaluation.

No interaction was verified among levels of $\mathrm{N} \times$ evaluation periods for growth, senescence and intake of leaf blades $(\mathrm{kg} / \mathrm{ha} \mathrm{DM})$ flows, intake of forage $(\mathrm{g} / \mathrm{kg} \mathrm{BW})$, potential efficiency (PUE), actual utilization efficiency (AUE) and net balance $(\mathrm{P}>0.05)$.

The leaf blade growth flow differed among the levels of $\mathrm{N}$ applied and the evaluation periods. 
The highest growth flow value was observed when using $100 \mathrm{~kg} / \mathrm{ha} \mathrm{N}$, an increase of $34.4 \%$ in relation to the other levels $(50.5 \mathrm{~kg} / \mathrm{ha} \mathrm{DM})$, which were not different to each other (Table 1). The leaf blade growth flow was higher by $58.3 \%$ in the first period of evaluation with respect to the second (Table 1).

The senescence flow was $35.6 \pm 6 \mathrm{~kg} / \mathrm{ha} \mathrm{DM}$ and similar between levels of $\mathrm{N}$. The highest senescence flow was observed in the first evaluation period (47.1 kg/ha DM), which was $23.2 \mathrm{~kg} / \mathrm{ha} \mathrm{DM}$ higher than in the second period $(\mathrm{P}=0.0025$; Table 1). A positive correlation between the senescence flow and canopy height was found $(r=0.67$; $\mathrm{P}=0.0013$ ).

The leaf blade intake flow (Table 1) and the leaf blade intake $(9.5 \mathrm{~g} / \mathrm{kg})$ were similar between $\mathrm{N}$ levels applied but differed between the evaluation periods. The Leaf blade intake flow was reduced by $27.5 \%$ in the second evaluation period compared to the first one (Table 1). Leaf blade intake flow was associated with the leaf:stem ratio $(r=0.51$; $\mathrm{P}=0.0215$ ).

The net balance $(3.2 \mathrm{~kg} / \mathrm{ha} /$ day $\mathrm{DM}$ leaf blade) was similar between the levels of $\mathrm{N}$ and differed between the periods. In the first period, the balance between the flows was positive $(17 \mathrm{~kg} / \mathrm{ha}$ DM leaf blade) and negative $(-2.3 \mathrm{~kg} / \mathrm{ha} /$ day $\mathrm{DM}$ leaf blade) in the second period.

The potential use efficiency (PUE; $0.2 \pm 0.07$ ) was similar and positive among $\mathrm{N}$ levels and evaluation periods. The actual utilization efficiency (AUE) differed between $\mathrm{N}$ levels and evaluation periods (Table 1). The AUE was higher when applied Zero, 200 and $300 \mathrm{~kg} / \mathrm{ha} \mathrm{N}$ in relation to AUE at $100 \mathrm{~kg} / \mathrm{ha} \mathrm{N}(0.22$; Table 1). The AUE was higher in the second period compared to the first ( 0.46 vs 0.26 , respectively).

\section{DISCUSSION}

Meteorological data of the experimental period showed that the average temperature observed was similar to the historical average temperature $\left(21.3^{\circ} \mathrm{C}\right)$. Rainfall amounts were higher than the historical averages, $54.4 \%$ (December; $133.5 \mathrm{~mm}$ ), 19.6\% (March, $151.7 \mathrm{~mm}$ ) and 8.8\% (April; $134.7 \mathrm{~mm}$ ). In February, the observed rainfall was $25 \%$ below the historical average (130.2 $\mathrm{mm})$.

The value of forage mass (FM) in the paddocks used to evaluate $\mathrm{N}$ levels was in accordance with the experimental protocol. In Alexandergrass, this value does not allow early elongation of internodes and, consequently, prevents the quality reduction of forage as grazed
(SALVADOR et al., 2014). Oliveira Neto et al., (2013) managed Alexandergrass pasture with FM around $3000 \mathrm{~kg} / \mathrm{ha} \mathrm{DM}$, which allowed nutritional support for grazing heifers be mated at 18 months of age.

The canopy height ensured similar conditions of forage selection by grazing animals. The association between canopy height and stem length points out the positive relationship between these two variables. In tropical forages, the stem has an important effect on the variation of sward structure and on the balance of competition for light (CRUZ; BOVAL, 2000). As a result of a similar forage selection in all paddocks, the leaf:stem ratio (LSR) was also similar. The reduction in LSR observed in the second evaluation period is predictable, due the approach of the reproductive phase of Alexandergrass, reducing the emergence of new leaf blades.

The leaf appearance rate is mainly influenced by variations in temperature and stem length (LEMAIRE; CHAPMAN, 1996), being independent of $\mathrm{N}$ levels used. According to Duru, Feuillerac and Ducrocq (1999), for a given level of $\mathrm{N}$, under stable weather conditions, the phyllochron depends on the leaf blade length of the preceding leaf. The highest leaf appearance rate and the lowest phyllochron, observed in the first period, determined the maximum number of green leaves per tiller at that time. In the second period, it may have occurred the change from vegetative to pre-flowering stage and, on that basis the structure of the plant was modified by increasing the production of reproductive structures at the expense of production of leaf blades.

The lack of effect of $\mathrm{N}$ and evaluation periods on the leaf lifespan can be due to this variable being genetically determined, although it is also influenced by environmental factors (POMPEU et al., 2009). Leaf lifespan can be considered an important factor in determining the grazing efficiency under continuous stocking. Forage species with longer leaf lifespan present higher chances to have their leaves defoliated before the onset of senescence (LEMAIRE et al., 2009).

The leaf expansion rate is one of the morphogenetic characteristics most influenced by nitrogen fertilization and, in tropical forage grasses, its response to $\mathrm{N}$ levels is linear and positive (GARCEZ NETO et al., 2002; Oliveira et al., 2007). This pattern of response, however, was not observed in Alexandergrass herein. When using levels of 200 and $300 \mathrm{~kg} / \mathrm{ha} \mathrm{N}$, leaf expansion rate has been limited, probably due to the genetic trait of Alexandergrass, a plant considered invasive with 
reduced potential for $\mathrm{N}$ absorption (ADAMI et al., 2010). Furthermore, when applied high N quantity to plants with low absorption capacity, the nutrient can be easily lost by leaching and volatilization.

The decrease in light and temperature with the approach of autumn and plus the reduction of $\mathrm{N}$ requirements of plants due to the early reproductive stage (LEMAIRE; CHAPMAN, 1996) may explain the lower leaf expansion in the second period. The annual cycle of Alexandergrass can also explain the reduction in leaf expansion rate, as this forage grows during warmer seasons, flowering and disappearing at lower temperatures.

The effect of nitrogen fertilization on the stem growth rate is dependent on plant growth habit. In the vegetative developmental stage of tufted grasses, in response to additional $\mathrm{N}$, only leaf blades are produced; while in stoloniferous grasses, both leaves and stolons are produced (CRUZ; BOVAL, 2000). Alexandergrass has cespitosus/decumbent growth habit and, according the management used, it presented a predominantly cespitosus growth and did not show difference in stem expansion in response to $\mathrm{N}$ fertilization.

The use of continuous stocking grazing method, with similar canopy height for the $\mathrm{N}$ levels, may also have influenced the stem expansion rate. In intermittent grazing, for the cultivar Mombaça (Panicum maximum cv. Mombaça), Cândido et al. (2005) observed that the increased canopy height after the interval between grazings triggered a photomorphogenic response, characterized by stem elongation.

The lack of nitrogen supply, at Zero dose, may have increased internal remobilization of $\mathrm{N}$, accelerating senescence. From $100 \mathrm{~kg} / \mathrm{ha} \mathrm{N}$ onwards, internal remobilization may have been minimized. The resorption efficiency of $\mathrm{N}$ is higher in pastures that receive low amount in comparison with high amounts of nitrogen fertilizer (ADAMI et al., 2010). During the senescence process, the leaf specific mass decreases asymptotically as a consequence of carbohydrates intake in order to maintain respiratory activity (LEMAIRE; CHAPMAN, 1996).

The positive association between leaf senescence rate and stem length probably corresponds to the greater shading of the leaf blades at the lower layer of the canopy increasing the aging process. Low solar radiation on these blades combined with the low availability of $\mathrm{N}$ in the soil leads to remobilization of nutrients, directing them to the cell multiplication zone of the tiller, where there is expansion of new leaves. The duration of leaf blade expansion is associated with the leaf blade length and, although it was observed higher leaf blade expansion rate when applied $100 \mathrm{~kg} / \mathrm{ha} \mathrm{N}$, this increment was not sufficient to change the length of leaf blades of Alexandergrass.

The stem expansion rate and leaf blade length variables can be explained together because there is a close relationship between the processes taking place within the leaf sheath. For certain growth conditions, the appearance of the leaf corresponds to cessation of cell proliferation, after which there is only the cell expansion phase and, therefore, stem height determines the number of cells and, therefore, the length of the leaf blade (DURU; DUCROCQ, 2000).

The similarity registered in the number of green leaves can be explained by the fact that number of green leaves per tiller is relatively constant, genetically determined, and at the vegetative stage, the production of leaf tissue is the priority for the plant.

In the second evaluation period, the negative linear behavior of the number of green leaves according to nitrogen levels resulted in reduction of 0.0017 green leaves per tiller per $\mathrm{kg} \mathrm{N}$ applied. On that occasion, probably corresponding to the onset of the pre-flowering stage, the increased availability of this nutrient was used for the development of the reproductive organs of the plant. In each of the developmental stage of the forage, the structural characteristics of the plant may vary depending on local availability of nutrients, physiological age of the tiller and potential response of these tillers to management practices (PAIVA et al., 2012).

A direct link exists between the rate of appearance of leaf blades, similar between the $\mathrm{N}$ levels evaluated, and tiller population density. The potential for tillering is determined by this link. Tiller production is influenced by the interaction of several factors such as light and nutrients. Although the availability of $\mathrm{N}$ may change the tillering potential, it did not occur in this study. On the other hand, the similarity of forage mass and canopy height in the different levels of $\mathrm{N}$ were probably the main factors determining the number of tillers that remained alive. Under continuous grazing, the tiller density is primarily determined by the balance of leaf area index of the canopy (LEMAIRE; CHAPMAN, 1996).

The observed grazing intensity was greater than the value (50-55\%) reported by Lemaire et al., (2009), who considered this value as a constant. Greater intensities of removal of leaf blades can influence the photosynthetic efficiency of leaves, making them less efficient in relation to 
undefoliated leaves. This leaf tissue removal, however, can stimulate the remobilization of the tiller assimilates for the expansion of a new leaf with increased photosynthetic capacity. Then, higher removal intensities may provide greater renewal of foliar tissues in the canopy (MARCELINO et al., 2006).

At levels Zero, 100 and $300 \mathrm{~kg} / \mathrm{ha} \mathrm{N}$ and average temperature of $22.5^{\circ} \mathrm{C}$, the frequency of return to the same tiller was 3.7 times before the senescence of a leaf blade, considering its leaf lifespan of 534.6 degree-day. Utilizing $200 \mathrm{~kg} / \mathrm{ha} \mathrm{N}$, the heifers returned 4.3 times to the same tiller before the senescence of a leaf blade. The greater return to the same blade before its senescence indicates a greater grazing efficiency. In accordance with Lemaire (1997), efficiency is defined as the proportion of produced leaf blades that are consumed by animals before the onset of the senescence process. According to Lemaire and Agnusdei (2000), the return rate is closely related to the stocking rate. In continuous stocking, the higher the stocking, the more frequent are defoliation, that is, the greater the number of times that a leaf is grazed by the animal in a given time interval.

The maintenance of a greater leaf blades mass in the canopy using $100 \mathrm{~kg} / \mathrm{ha} \mathrm{N}$ may have maximized photosynthesis, due to higher interception of solar radiation, resulting in increased growth flow. Also, the highest leaf expansion rate of Alexandergrass with $100 \mathrm{~kg} / \mathrm{ha} \mathrm{N}$ was also responsible for the increasing of leaf growth flow. Regardless of $\mathrm{N}$ dose applied, the growth flow of leaf blades was higher than that found in Alexandergrass (27.5 kg ha/day DM) by Eloy et al., (2014).

The reduced growth flow of leaf blades in the second period of evaluation compared to the first (Table 1) can be explained by the reduction in $18.14 \%$ of the incident solar radiation from the previous period, because the rate of expansion of leaf blades is dependent on light (LEMAIRE; CHAPMAN, 1996). Besides the reduction in the solar radiation, the reduced growth flow of leaf blades can also be explained by the annual cycle of Alexandergrass, which makes the species to complete its cycle in the late summer and early fall (BOGDAN, 1977).

The similarity in senescence flow between $\mathrm{N}$ levels may have been a result of the similar canopy height. The observed association between these variables highlights the role of canopy height in the amount of sunlight that reaches its lower layer, interfering leaf senescence rate. In the second evaluation period, the canopy height was lower, allowing more light to reach the canopy layer next soil and resulting in lower leaf senescence.

The estimated forage intake by heifers with similar age and weight, as those used in this experiment, is $23 \mathrm{~g} / \mathrm{kg}$ of body weight (BW; NRC, 1996). With an average weight of $273 \mathrm{~kg} \mathrm{BW}$, the expected intake by a grazing heifer would be 6.3 $\mathrm{kg} /$ day DM. The number of heifers/ha was 6.5 and, considering the value of intake flow, each heifer would have consumed $2.2 \mathrm{~kg}$ DM leaf blade, which represents $34.7 \%$ of the estimated daily intake of the DM. Heifers reached an average daily gain of 0.7 $\mathrm{kg} / \mathrm{day}$, indicating that the stem intake complements the required amount for this gain.

The association between the leaf blade intake flow and leaf:stem ratio shows that higher is the value of this variable, greater is the easiness of forage grasping and, therefore, the bite size, considering stems as a physical barrier for bite formation (BENVENUTTI, GORDON; POPPI, 2006). The leaf: stem ratio, similar among $N$ levels, may have been responsible for similar intake flow. Thus, the lowest amount of leaf blades produced in the second period may explain the lower leaf blades intake flow at that time.

The positive net balance between biomass flows, regardless of $\mathrm{N}$ application, indicates that growth flow was greater than the flows of senescence and intake. In the first evaluation period, the positive balance between the flows may have been influenced by the higher growth flow of leaf blades. In the second period, the negative balance indicates that senescence and intake were higher than the growth of leaf blades of Alexandergrass.

The similar and positive potential use efficiency in all $\mathrm{N}$ levels and evaluation periods was due to the growth flow $29.5 \%$ higher than the senescence flow in all $\mathrm{N}$ levels evaluated. The value of actual utilization efficiency (AUE) below the unity indicates that the heifers consumed a leaf blades amount lower than the amount produced. When the levels Zero, 200 and $300 \mathrm{~kg} / \mathrm{ha} \mathrm{N}$ were applied, the intake flow was 3.6 times lower than the growth flow. When $100 \mathrm{~kg} / \mathrm{ha} \mathrm{N}$ was applied, occurred the lowest AUE and the intake flow was 5.5 times lower than the growth flow. Management of pastures keeping adequate forage mass and canopy height may allow to be kept in the canopy an adequate leaf area for regrowth. Probably, that has occurred in all $\mathrm{N}$ levels evaluated. The highest AUE in the second evaluation period may have occurred due to the lower growth of leaf blades. 


\section{CONCLUSIONS}

In Alexandergrass pastures, it is recommended the use of $100 \mathrm{~kg} / \mathrm{ha} \mathrm{N}$ to maximize the leaf blades growth flow.

The herbivore-plant relationship, according to frequency of return to the leaf blade by animals is altered by the applications of $\mathrm{N}$ levels.
The use of differents levels of $\mathrm{N}$ in Alexandergrass does not change the intensity of removal of leaf blades.

\section{ACKNOWLEDGEMENTS}

The authors thank the Research Foundation of the Rio Grande do Sul State (FAPERGS) for the financial support to this research.

RESUMO: A determinação dos fluxos de biomassa pode auxiliar no aperfeiçoamento das técnicas de adubação de pastagens, pois contribui para a identificação das melhores formas de manejo, que incluem o uso de fertilizantes. A deficiência de $\mathrm{N}$ em pastagens pode reduzir a produção de forragem. Por outro lado, existe uma preocupação ambiental relativa às perdas de nitrogênio $(\mathrm{N})$ quando esse nutriente é utilizado em excesso e essa preocupação direciona a pesquisa para novos sistemas de pastejo que otimizem o uso deste nutriente. Os fluxos de biomassa foliar, a intensidade e frequência de desfolha foram avaliados quando o papuã (Urochloa plantaginea (Link) Hitch) foi adubado com Zero, 100, 200 ou $300 \mathrm{~kg} / \mathrm{ha}$ de nitrogênio $(\mathrm{N})$, na forma de ureia. O método de pastejo foi contínuo com número variável de animais para manter a massa de forragem em $3000 \mathrm{~kg} / \mathrm{ha}$ de MS. Os animais experimentais foram bezerras Angus com idade e peso corporal médio inicial de 15 meses e $241,5 \pm 5 \mathrm{~kg}$, respectivamente. O delineamento experimental foi inteiramente casualizado, com medidas repetidas no tempo, com quatro tratamentos e número variável de unidades experimentais. $\mathrm{O}$ uso de $100 \mathrm{~kg} / \mathrm{ha}$ de $\mathrm{N}$ proporcionou maior fluxo de crescimento de lâminas foliares. Os fluxos de senescência e de consumo e a intensidade de desfolha foram similares nos níveis de $\mathrm{N}$ utilizados. A frequência de retorno dos animais ao mesmo perfilho (dias) foi influenciado pelos níveis de $\mathrm{N}$ e períodos de avaliação. É recomendada a utilização de $100 \mathrm{~kg} / \mathrm{ha}$ de $\mathrm{N}$ em pastagem de papuã.

PALAVRAS-CHAVE: Morfogênese. Pastejo contínuo. Ureia. Urochloa plantaginea (Link) Hitch.

\section{REFERENCES}

ADAMI, P. F.; SOARES, A. B.; ASSMANN, T. S.; ASSMANN, A. L.; SARTOR, L. R.; PITTA, C. S. R.; FRANCHIN, M. F.; MIGLIORINI, F. Dynamic of a papuã pasture under two grazing intensities and two nitrogen levels. Revista Brasileira de Zootecnia, Viçosa, v. 39, n. 12, p. 2569-2577, dez. 2010. http://dx.doi.org/10.1590/S1516-35982010001200003

BENVENUTTI, M. A.; GORDON, I. J.; POPPI, D. P. The effect of density and physical properties of grass stems on the foraging behavior and instantaneous intake rate by cattle grazing an artificial reproductive tropical sward. Grass and Forage Science, Oxford, v. 61, n. 3, set. p. 272-281, 2006.

http://onlinelibrary.wiley.com/doi/10.1111/j.1365-2494.2006.00531.x/full

BIRCHAM, J. S.; HODGSON, J. The influence of sward condition on rates of herbage growth and senescence in mixed swards under continuous stocking management. Grass and Forage Science, Oxford, v. 38, n. 4, p. 323-331, dez. 1983. http://onlinelibrary.wiley.com/doi/10.1111/j.1365-2494.1983.tb01656.x/full

BOGDAN, A.V. Tropical pastures and fodder plants: grasses and legumes. London: Longman Handbooks, 1977. 475p.

CÂNDIDO, M. J. D.; GOMIDE C. A. M.; ALEXANDRINO E.; GOMIDE, J. A.; PEREIRA, W. E. Morfofisiologia do dossel de Panicum maximum cv. Mombaça sob lotação intermitente com três períodos de descanso. Revista Brasileira de Zootecnia, Viçosa, v. 34, n. 2, p. 406-415, mar. 2005. http://www.scielo.br/pdf/\%0D/rbz/v34n2/25451.pdf

CARRERE, P.; LOUAULT, F.; SOUSSANA J. F. Tissue turnover within Grass-clover mixed sward grazed by sheep. Methodology for calculating growth, senescence and intake fluxes. Journal of Applied Ecology, Oxford, v. 34, n. 2, p. 333-346, abr. 1997. http://www.jstor.org/stable/2404880?seq=1\#page_scan_tab_contents 
CRUZ, P.; BOVAL, M. Effect of nitrogen on some morphogenetic traits of temperate and tropical perennial forage grasses. p. 151-168. In: LEMAIRE, G.; HODGSON, J.; MORAES, A. (Eds.) Grassland ecophysiology and grazing ecology. Wallingford: CABI Publishing. 2000.

DURU, M.; FEUILLERAC, E.; DUCROCQ, H. In vitro digestibility response of cocksfoot (Dactylis glomerata L.) to growth and defoliation: a simple model. Journal of Agricultural Science, Cambridge, v. 133, n. 4, p. 379-388, ago. 1999. https://www.cambridge.org/core/journals/journal-of-agricultural-science/article/invitro-digestibility-response-of-cocksfoot-dactylis-glomerata-1-to-growth-and-defoliation-a-simplemodel/FDDE05CEFDF326460FA27547CDAACFC1

DURU, M.; DUCROCQ, H. Growth and senescence of the successive leaves on a Cocksfoot tiller. Effect of nitrogen and cutting regime. Annals of Botany, London, v. 85, n. 5, p. 645-653, jan. 2000.

http://aob.oxfordjournals.org/content/85/5/645.short

ELOY, L. R.; ROCHA, M. G.; PÖTTER, L.; SALVADOR, P. R.; STIVANIN, S. C. B.; HAMPEL, V. S. da. Biomass flows and defoliation patterns of alexandergrass pasture grazed by beef heifers, receiving or not protein salt. Acta Scientiarum. Animal Sciences, Maringá, v. 36, n. 2, p. 123-128, jun. 2014.

http://dx.doi.org/10.4025/actascianimsci.v36i2.21815

Empresa Brasileira de Pesquisa Agropecuária - EMBRAPA. 2006. Centro Nacional de Pesquisa em Solos. Sistema brasileiro de classificação de solos. Brasília: EMBRAPA-SPI. Rio de Janeiro. EMBRAPA Solos. 306p.

GARCEZ NETO, A. F.; JUNIOR D. N.; REGAZZI A. J.; FONSECA, D. M. da; MOSQUIM, P. R.; GOBBI, K. F. Respostas morfogênicas e estruturais de Panicum maximum cv. Mombaça sob diferentes níveis de adubação nitrogenada e alturas de corte. Revista Brasileira de Zootecnia, Viçosa, v. 31, n. 5, p. 1890-1900, out. 2002. http://www.scielo.br/pdf/\%0D/rbz/v31n5/a04v31n5.pdf

HERINGER, I.; CARVALHO, P. C. F. Ajuste da carga animal em experimentos de pastejo: uma nova proposta. Ciência Rural, Santa Maria, v. 32, n. 4, p. 675-679, ago. 2002. http://dx.doi.org/10.1590/S010384782002000400021.

LEMAIRE, G.; CHAPMAN, D. Tissue flows in grazed plant communities. p. 3-36. In: HODGSON, J; ILLIUS, A. W. (Eds.). The ecology and management of grazing systems. Wallingford: CAB International. 1996.

LEMAIRE, G. The physiology of grass growth under grazing: tissue turnover. p. 117-144. Simpósio internacional sobre produção animal em pastejo. 1997.

LEMAIRE, G.; AGNUSDEI, M. Leaf tissue turn-over and efficiency of herbage utilization. p. 165-186. In: LEMAIRE, G.; HODGSON, J.; MORAES, A.; CARVALHO, P. C. F.; NABINGER, C. (ed.) Grassland ecophysiology and grazing ecology, Wallingford: CABI publishing. 2000.

LEMAIRE, G.; DA SILVA S. C.; WADE N.; HODGSON, J. Interactions between leaf lifespan and defoliation frequency in temperature and tropical pastures: a review. Grass and Forage Science, Oxford, v. 64, n. 4, p. 341-353, nov. 2009. http://onlinelibrary.wiley.com/doi/10.1111/j.1365-2494.2009.00707.x/full

LOPES, M. N.; CÂNDIDO, M. J. D.; POMPEU, R. C. F. F.; DA SILVA, R. G. da; CARVALHO, T. C. F.; SOMBRA, W. A.; MORAIS NETO, L. B. M.; PEIXOTO, M. J. A. Biomass flow in massai grass fertilized with nitrogen under intermittent stocking grazing with sheep. Revista Brasileira de Zootecnia, Viçosa, n. 42, v. 1, p. 13-21, jan. 2013. http://dx.doi.org/10.1590/S1516-35982013000100003

MARCELINO, K. R. A.; JUNIOR, D. N.; DA SILVA, S. C.; EUCLIDES, V. P. B.; FONSECA, D. M. da. Características morfogênicas e estruturais e produção de forragem do capim-marandu submetido a intensidades e frequências de desfolhação. Revista Brasileira de Zootecnia, Viçosa, v. 35, n. 6, p. 2243-2252, dez. 2006. http://dx.doi.org/10.1590/S1516-35982006000800007 
MARTINS, J. D.; RESTLE, J.; BARRETO I. L. Produção animal em Capim Papuã (Brachiaria plantaginea (Link) Hitchc) submetido a níveis de nitrogênio. Ciência Rural, Santa Maria, v. 30, n. 5, p. 887-892, out. 2000. http://dx.doi.org/10.1590/S0103-84782000000500025

NRC - NATIONAL RESEARCH COUNCIL. Nutrient requirement of beef cattle. 7. ed. Washington: National Academy. 90p. 1996.

OLIVEIRA, A. B.; PIRES, A. J. V.; NETO, U. M.; CARVALHO, G. P. de; VELOSO, C. M.; DA SILVA, F. F. Morfogênese do capim-tanzânia submetido a adubações e intensidades de corte. Revista Brasileira de Zootecnia, Viçosa, v. 36, n. 4, p. 1006-1013, ago. 2007. http://dx.doi.org/10.1590/S1516-35982007000500004

OLIVEIRA NETO, R. A. de; SILVA, J. H. S.; ROCHA, M. G.; PÖTTER, L.; SICHONANY, M. J. O.; BISCAÍNO, L. L.; SANTOS, F. A. dos; DIFANTE, M. V. B. Ingestive behavior, performance and forage intake by beef heifers on tropical pasture systems. Revista Brasileira de Zootecnia, Viçosa, v. 42, n. 8, p. 549558, ago. 2013. http://dx.doi.org/10.1590/S1516-35982013000800003

PAIVA, A. J.; DA SILVA, S. C.; PEREIRA, L. E. T.; GUARDA, V. D.; PEREIRA P. M.; CAMINHA F. O. Structural characteristics of tiller age categories of continuously stocked marandu palisade grass swards fertilized with nitrogen. Revista Brasileira de Zootecnia, Viçosa, v. 41, n. 1, p. 24-29, jan. 2012. http://dx.doi.org/10.1590/S1516-35982012000100004

POMPEU, R. C. F. F.; CÂNDIDO, M. J. D.; NEIVA, J. N. M.; ROGÉRIO, M. C. P.; BENEVIDES, Y. I.; OLIVEIRA, B. C. M. de. Fluxo de biomassa em capim-tanzânia sob lotação rotativa com quatro níveis de suplementação concentrada. Revista Brasileira de Zootecnia, Viçosa, v. 38, n. 5, p. 809-817, mai. 2009. http://dx.doi.org/10.1590/S1516-35982009000500005

PONTES, L. S.; CARVALHO. P. C. F.; NABINGER, C. Fluxo de biomassa em pastagem de azevem anual (Lolium multiflorum Lam.) manejada em diferentes alturas. Revista Brasileira de Zootecnia, Viçosa, v. 33, n. 3, p. 529-537, jun. 2004. http://dx.doi.org/10.1590/S1516-35982004000300002

ROLAS. Manual de adubação e de calagem para os Estados do Rio Grande do Sul e de Santa Catarina / Sociedade Brasileira de Ciência do Solo. Comissão de Química e Fertilidade do Solo. Ed. 10, 400 p. 2004.

SALVADOR, P. R.; PÖTTER, L.; ROCHA, M. G.; ELOY, L. R.; HAMPEL, V. S. da; STIVANIN, S. C. B.; ROSA, A. T. N. da; SICHONANY, M. J. O. Fluxos de tecidos foliares em papuã sob pastejo de bezerras de corte em diferentes frequências de suplementação. Revista Brasileira de Saúde e Produção Animal, Salvador, v. 15, n. 4, p. 835-845, dez. 2014. http://revistas.ufba.br/index.php/rbspa/article/view/3113/1637

SARTOR, L. R.; ASSMANN, T. S.; SOARES, A. B.; ADAMI, P. F.; ASSMANN, A. L.; ORTIZ, S. Assessment of the nutritional status of grassland: nitrogen nutrition index. Semina. Ciências Agrárias, Londrina, v. 35, n. 1, p. 449-456, fev. 2014. http://dx.doi.org/10.5433/1679-0359.2014v35n1p449 